\title{
Language Attitude of Basa Osing Speakers in Banyuwangi
}

\author{
Ressi Maulidina Delijar ${ }^{1}$, Hamamah $^{2}$, Ika Nurhayani ${ }^{3}$ \\ Fakultas Ilmu Budaya, Universitas Brawijaya Malang \\ ressimdelijar@gmail.com
}

\begin{abstract}
This research aims to determine the language attitude of Basa Osing speakers. This research is important because of the debate over the Basa Osing linguistic status which considers that Basa Osing is only a variation of Javanese, and the other assumption that Basa Osing is an independent local language. The highlight of the debate was when the Governor of East Java removed Basa Osing from the curriculum of local content. It will affect the attitudes and behavior of Osing speakers, especially young speakers. This research used quantitative method and involved 100 participants around Banyuwangi. The instruments used to collect data were questionnaires. This research proved that there is decline of positive attitudes shown between generation to generation (group I score $=3.19$, group $2=3.23$, group $3=3.87$ ). Basa Osing is very possible to experience language shifts in the future if the perspective of the society gets worse.

Keywords: Basa Osing; Banyuwangi; Javanese, language attitude;language shift.
\end{abstract}

\section{Intisari}

Penelitian ini bertujuan untuk mengetahui sikap bahasa penutur Basa Osing. Penelitian ini penting karena adanya perdebatan mengenai status linguistik Basa Osing yang dianggap sebagai hanya variasi dari bahasa Jawa, dan asumsi lain bahwa Basa Osing adalah bahasa yang independen. Puncak dari perdebatan adalah ketika Gubernur Jawa Timur menghapus Basa Osing dari kurikulum muatan lokal, yang dikhawatirkan akan mempengaruhi sikap dan perilaku penutur Osing, terutama penutur muda. Penelitian ini menggunakan metode kuantitatif dan melibatkan 100 peserta di sekitar Banyuwangi. Penelitian ini membuktikan bahwa ada penurunan sikap positif yang ditunjukkan antar generasi ke generasi (skor kelompok I = 3,19, kelompok $2=3,23$, kelompok $3=3,87$ ). Basa Osing sangat mungkin untuk mengalami pergeseran bahasa di masa yang akan datang jika masyarakat menunjukkan sikap yang semakin buruk.

Kata kunci; Basa Osing, Banyuwangi, bahasa Jawa, sikap bahasa, pergeseran bahasa.

\section{Introduction}

Indonesia consists of thousands tribes and languages. According to Badan Pusat Statistik (2012), there are 1.211 local languages exist in this archipelago. One language can create many dialects, as well as in Javanese language. Among 100 million speakers, Javanese creates many dialects as it spread over many regions. Jawa-Osing considered as one of Javanese dialects used in Banyuwangi, East Java, since Banyuwangi people often use "Using [osen]" to express disagreement or say no. This word is derived from Bali language "tusing" which 
means "no" (Arps, 2010:231). Another example from Arps (2010), unique vocabularies found in Jawa-Osing dialect are also obtained from the English (obtained at the time of colonization), such as nagud from the word no good which means "bad", enjong from the word enjoy which means "delicious (for food), fun (to express something exciting)". Therefore, it can be said that Jawa-Osing is influenced by Bali language, English, and Javanese itself.

At first, Jawa-Osing was only known as one of Javanese dialect, but, Herusantosa (1987), linguist from Singaraja, said that Jawa-Osing and Javanese are parallel in genealogical-language, both of them are the evolution of Old Javanese. This statement marked as the origin of the birth of Basa Osing, which formerly regarded only as a dialect of Javanese, currently declared as a language in Sarasehan Basa Osing 1990 and after Kongres Bahasa Jawa II in Batu, Malang, Basa Osing was approved as a local language which was taught in elementary and high school in Banyuwangi. Besides this political boundary that made Basa Osing as independent language, not dialect, Basa Osing also has some different vocabularies which Javanese people may not understand at all. For example, "Cumpu, dhonge didalakaken, iyane sing inguk paran-paran" (Arps, 2010:236). This simple sentence means "Apparently, after finding the best way, he cannot do anything at all". It shows that Javanese and Basa Osing have less mutual intelligibility.

Basa Osing caused many debates over its linguistic status. The decision of Banyuwangi government to include this language into the school curriculum also caused many protests in some sub-districts especially in which the majority of the population was not Basa Osing speakers (Arps, 2010: 239). The ethnic composition of Banyuwangi is predominantly Javanese, followed by Madurese, Osing (the indigenous people), Peranakan-Chinese (people of Chinese descent who became native by living for many generations in Indonesia), and some other ethnic groups (Legene, Purwanto, \& Nordholt, 2015). However, even with this kind of situation, Basa Osing still exists and used in Banyuwangi.

Nowadays, Basa Osing is officially removed from school curriculum based on Peraturan Gubernur Jawa Timur No. 19 of 2014 concerning Local Content of Regional Languages in the implementation of 2013 curriculum. In this regulation, local languages that used in school are only Javanese and Madurese. As Basa Osing being removed from the 
curriculum, Basa Osing is considered as only Javanese with different "accent", and Basa Osing does not have standard grammar.

Generalization of local language as it has happened, may influence the young generations to not use Basa Osing anymore in the future and shift to Javanese usage only. The next generations may not know this language at all. Many schools prefer to teach their students with various foreign languages, like Mandarin, English, German, and Japanese. They prepare for international standard, by forgetting the local one. Thus, the motivation of the young generation to still use Basa Osing is being questioned at this time.

The attitude of the speakers, in this case, is not about attitude in learning Basa Osing in the classroom, but motivation to still use language in everyday life. Since Basa Osing is a local language, if the attitude of its users is negative, it might impacts on language extinction in the future. On the contrary, positive attitude can help to preserve Basa Osing.

The present study is worth-conducting since as far as the writer's knowledge there is only limited study in Basa Osing, especially using sociolinguistics point of view. Mostly, Basa Osing is investigated from the phonological point of view. For example, Surani, et al (1987) wrote about the phonological system of Javanese varieties in Banyuwangi's dialect. Research about Basa Osing was also conducted by Maulidya (2015) to find out lexical differences in Osing variety spoken by people in Banyuwangi regency. Not only that, Budiono (2015) also wrote about language varieties in Banyuwangi Regency using dialectology point of view. Since there is limited research about language attitude of Basa Osing speakers before, this study needs to be conducted to investigate Basa Osing from the other point of view to gain new insight of this language. Additionally, the Governor of East Java regulation to remove Basa Osing as a local content on the grounds that Osing is "only" variation of the Javanese accent needs to be reconsidered because according to sociolinguistic characters, Basa Osing is an independent language and different from Javanese. This regulation besides being able to make Basa Osing will be more forgotten, it will also affect the attitude of its users because according to Jendra (2010: 115), some people show a positive attitude by claiming that the language or variation they used, regarded as standard, but they show negative attitudes towards the dialect of the same language regarded as standard by others. Therefore, this 
research is significant to do because this study measure the attitude of Banyuwangi people who speak both languages, Basa Osing and Javanese.

Language attitude in this research used to measure their language pride, language loyalty, and awareness of the language norms (Garvin and Mathiot, 1968) in order to investigate whether this language is vibrant, on the process of shifting to another language, or threatened. This is important since there was generalization between them. This study compares Basa Osing and Javanese to gain information on people's opinion on the existence of each language separately. To be highlighted, this research does not consider Basa Osing as only "different accent" of Javanese as stated by the Governor of East Java.

\section{Research Methods}

A quantitative was adopted to investigate and describe the language attitude of Basa Osing speakers in Banyuwangi. The primary data in this research was generated from the language attitude of Banyuwangi people toward Basa Osing. Data source was derived from the results of the questionnaire. A questionnaire distributed online with Google Forms and for the participants who are willing to be involved. For participants that cannot operate the Google forms, especially for those who are in the range age of more than 50 years, were directly interviewed by using the same questions. The model questionnaire is adapted from Cohn et al (2013) about language attitude and language use (attitude towards local language, Bahasa Indonesia, and English), but the questionnaire were modified to be relevance with this study. The questionnaire compared both local languages (Basa Osing and Javanese) by considering 3 aspects of positive attitude by Garvin and Marthiot (1968). Participants involved are in the range of age minimum 15 - 64 years old. Sampling technique used in this research is purposive random sampling. Purposive Random Sampling is a sampling technique used if the researcher has certain considerations for a particular purpose. The sample size is measured using Slovin (1960) formula (cited from Putra and Welly, 2015:903).

$$
\begin{gathered}
\mathrm{n}=\mathrm{N} / \mathrm{N}(\mathrm{d}) 2+1 \\
\mathrm{n}=\text { sample } ; \mathrm{N}=\text { population } ; \mathrm{d}=\text { precision value } 90 \% / \mathrm{sig} .=0,1 . \\
\mathrm{n}=76.163 / 76.163(0,1) 2+1 \\
\mathrm{n}=99,86 \text { (or approximately } 100 \text { people) }
\end{gathered}
$$


From the formula above, it shows that total sample size that will be observed is 100 people of Banyuwangi sub-district citizens and divided into three groups, first group (15 - 24 years old), second group (25 - 34 years old), and third group (>35 years old).

\section{Findings and Discussions}

Related to Garvin \& Mathiot (1968) characteristic of positive attitude, the data are presented with language pride, language loyalty, and awareness of the norms. First of all, group I is the group of 15-24 years old participants. Group I shows neutral attitude $\left(\sum=191.4 /\right.$ mean $=$ 3.19) towards their local language, Basa Osing, in general ( $\mathrm{N}=60$, see attachment 1$)$. Even this group shows neutral attitude, but they likely show more positivity in language pride, than language loyalty and awareness of the norms.

Group II is the group of 25-34 years old participants. Group II shows neutral attitude $\left(\sum=74.3 /\right.$ mean $\left.=3.32\right)$ towards their local language $(\mathrm{N}=23$, see attachment 2$)$. Even this group shows neutral attitude, but they likely show more positivity than the previous group (based on the score). Same as group I, this group also has more positivity in language pride aspect, than language loyalty and awareness of the norms. But in general, the three aspect scores of this group is better than group I.

Group III is the group of 35-64 years old participants. Among all the groups, group III shows most positive attitude $\left(\sum=65.8 /\right.$ mean $\left.=3.87\right)$ towards their local language $(\mathrm{N}=17$, see attachment 3). Different from other group of age, this group has the greatest score in language loyalty aspect. If it is compared with group I and II, group III outperformed all positive aspects of language attitude, i.e. language pride (mean $=3.96$ ), language loyalty $($ mean $=4.05)$, awareness of the norms $($ mean $=3.33)$.

\section{Language Pride}

As explained before, language pride usually manifests in respect and encourages a language user community to develop their language and make it into a social symbol or identity. With this high language pride, Basa Osing speakers in group I tend to consider that Basa Osing is theirs, and not belong to other region. In the aspect of language pride, group II shows a positive attitude of $83 \%$ and a neutral attitude of $17 \%$. This is quite an increase compared to group I which shows a positive attitude of $67 \%$. It shows that in the older range age, the perspective towards Basa Osing can change. Meanwhile, language pride group III looks the 
same as language pride in group II, because both consist of $83 \%$ positive attitudes and the rest are neutral attitudes. The difference is the average score of group II and III. Group III has a higher score. It shows the higher level of positivity of participants in group III in aspects of language pride. This attitude is reflected from the questions they answer below.

Table 1 Language Pride Score Based on The Age Groups

\begin{tabular}{|c|c|c|c|c|}
\hline & Statements & Group I & Group II & Group III \\
\hline Q1 & $\begin{array}{l}\text { Menguasai bahasa Osing lebih } \\
\text { penting dibandingkan dengan } \\
\text { bahasa Jawa } \\
\text { 'Mastering Osing is more important } \\
\text { than Javanese' }\end{array}$ & $\begin{array}{l}1(\mathrm{~N}=2) \\
2(\mathrm{~N}=8) \\
3(\mathrm{~N}=23) \\
4(\mathrm{~N}=17) \\
5(\mathrm{~N}=10) \\
\sum=((1 \times 2)+(2 \times 8)+ \\
(3 \times 23)+(4 \times 17)+ \\
(5 \times 10)): 60=\mathbf{3 . 4 2} \\
\text { (Positive Attitude) }\end{array}$ & $\begin{array}{l}1(\mathrm{~N}=1) \\
2(\mathrm{~N}=1) \\
3(\mathrm{~N}=12) \\
4(\mathrm{~N}=5) \\
5(\mathrm{~N}=4) \\
\sum=((1 \times 1)+(2 \times 1)+ \\
(3 \times 12)+(4 \times 5)+ \\
(5 \times 4)): 23=\mathbf{3 . 4 3} \\
\text { (Positive Attitude) }\end{array}$ & $\begin{array}{l}1(\mathrm{~N}=1) \\
2(\mathrm{~N}=1) \\
3(\mathrm{~N}=4) \\
4(\mathrm{~N}=4) \\
5(\mathrm{~N}=7) \\
\sum=((1 \times 1)+(2 \times 1)+ \\
(3 \times 4)+(4 \times 4)+(5 \times 7)): \\
17=\mathbf{3 . 8 8} \\
\text { (Positive Attitude) }\end{array}$ \\
\hline Q4 & $\begin{array}{l}\text { Berbicara dalam bahasa Osing itu } \\
\text { kuno } \\
\text { 'Speaking in Basa Osing is out-of- } \\
\text { date' }\end{array}$ & $\begin{array}{l}1(\mathrm{~N}=2) \\
2(\mathrm{~N}=4) \\
3(\mathrm{~N}=9) \\
4(\mathrm{~N}=7) \\
5(\mathrm{~N}=38) \\
\sum=((1 \times 2)+(2 \times 4)+ \\
(3 \times 9)+(4 \times 7)+ \\
(5 \times 38)): 60=\mathbf{4 . 2 5} \\
(\text { Positive Attitude })\end{array}$ & $\begin{array}{l}1(\mathrm{~N}=1) \\
2(\mathrm{~N}=0) \\
3(\mathrm{~N}=8) \\
4(\mathrm{~N}=4) \\
5(\mathrm{~N}=10) \\
\sum=((1 \times 1)+(2 \times 0)+ \\
(3 \times 8)+(4 \times 4)+ \\
(5 \times 10)): 23=\mathbf{3 . 9 6} \\
\text { (Positive Attitude) }\end{array}$ & $\begin{array}{l}1(\mathrm{~N}=1) \\
2(\mathrm{~N}=1) \\
3(\mathrm{~N}=2) \\
4(\mathrm{~N}=1) \\
5(\mathrm{~N}=12) \\
\sum=((1 \times 1)+(2 \times 1)+ \\
(3 \times 2)+(4 \times 1)+(5 \times 12)): \\
17=4.29 \text { (Positive } \\
\text { Attitude) }\end{array}$ \\
\hline Q6 & $\begin{array}{l}\text { Kalau mau menjadi bagian dari } \\
\text { suku Osing, seseorang perlu } \\
\text { menguasai bahasa Osing } \\
\text { 'If someone wants to be part of the } \\
\text { Osing tribe, someone needs to } \\
\text { master Basa Osing' }\end{array}$ & $\begin{array}{l}1(\mathrm{~N}=10) \\
2(\mathrm{~N}=8) \\
3(\mathrm{~N}=19) \\
4(\mathrm{~N}=12) \\
5(\mathrm{~N}=11) \\
\sum=((1 \times 10)+(2 \times 8)+ \\
(3 \times 19)+(4 \times 12)+ \\
(5 \times 11)): 60=\mathbf{3 . 1 0} \\
\text { (Neutral Attitude) }\end{array}$ & $\begin{array}{l}1(\mathrm{~N}=2) \\
2(\mathrm{~N}=2) \\
3(\mathrm{~N}=8) \\
4(\mathrm{~N}=4) \\
5(\mathrm{~N}=7) \\
\sum=((1 \times 2)+(2 \times 2)+ \\
(3 \times 8)+(4 \times 4)+(5 \times 7)): \\
23=\mathbf{3 . 5 2}(\text { Positive } \\
\text { Attitude) }\end{array}$ & $\begin{array}{l}1(\mathrm{~N}=0) \\
2(\mathrm{~N}=3) \\
3(\mathrm{~N}=3) \\
4(\mathrm{~N}=3) \\
5(\mathrm{~N}=8) \\
\sum=((1 \times 0)+(2 \times 3)+ \\
(3 \times 3)+(4 \times 3)+(5 \times 8)): \\
17=\mathbf{3 . 9 4} \text { (Positive } \\
\text { Attitude) }\end{array}$ \\
\hline Q7 & $\begin{array}{l}\text { Bahasa Jawa lebih baik daripada } \\
\text { bahasa Osing } \\
\text { 'Javanese is better than Basa } \\
\text { Osing' }\end{array}$ & $\begin{array}{l}1(\mathrm{~N}=3) \\
2(\mathrm{~N}=9) \\
3(\mathrm{~N}=24) \\
4(\mathrm{~N}=11) \\
5(\mathrm{~N}=13) \\
\sum=((1 \times 3)+(2 \times 9)+ \\
(3 \times 24)+(4 \times 11)+ \\
(5 \times 13)): 60=\mathbf{3 . 3 7} \\
\text { (Positive Attitude) }\end{array}$ & $\begin{array}{l}1(\mathrm{~N}=0) \\
2(\mathrm{~N}=2) \\
3(\mathrm{~N}=14) \\
4(\mathrm{~N}=3) \\
5(\mathrm{~N}=4) \\
\sum=((1 \times 0)+(2 \times 2)+ \\
(3 \times 14)+(4 \times 3)+ \\
(5 \times 4)): 23=3.39 \\
(\text { Positive Attitude })\end{array}$ & $\begin{array}{l}1(\mathrm{~N}=0) \\
2(\mathrm{~N}=2) \\
3(\mathrm{~N}=2) \\
4(\mathrm{~N}=1) \\
5(\mathrm{~N}=12) \\
\sum=((1 \times 0)+(2 \times 2)+ \\
(3 \times 2)+(4 \times 1)+(5 \times 12)): \\
17=4.35(\text { Positive } \\
\text { Attitude) }\end{array}$ \\
\hline Q10 & $\begin{array}{l}\text { Bahasa Osing adalah dialek bahasa } \\
\text { Jawa di Banyuwangi } \\
\text { 'Basa Osing is a Javanese dialect in } \\
\text { Banyuwangi' }\end{array}$ & $\begin{array}{l}1(\mathrm{~N}=22) \\
2(\mathrm{~N}=14) \\
3(\mathrm{~N}=12) \\
4(\mathrm{~N}=7) \\
5(\mathrm{~N}=5) \\
\sum=((1 \times 22)+(2 \times 14)\end{array}$ & $\begin{array}{l}1(\mathrm{~N}=8) \\
2(\mathrm{~N}=4) \\
3(\mathrm{~N}=5) \\
4(\mathrm{~N}=4) \\
5(\mathrm{~N}=2) \\
\sum=((1 \times 8)+(2 \times 4)+\end{array}$ & $\begin{array}{l}1(\mathrm{~N}=3) \\
2(\mathrm{~N}=7) \\
3(\mathrm{~N}=3) \\
4(\mathrm{~N}=0) \\
5(\mathrm{~N}=4) \\
\sum=((1 \times 3)+(2 \times 7)+\end{array}$ \\
\hline
\end{tabular}




\begin{tabular}{|c|c|c|c|c|}
\hline & & $\begin{array}{l}+(3 \times 12)+(4 \times 7)+ \\
(5 \times 5)): 60=\mathbf{2 . 3 2} \\
(\text { Neutral Attitude })\end{array}$ & $\begin{array}{l}(3 \times 5)+(4 \times 4)+(5 \times 2)): \\
23=\mathbf{2 . 4 8} \text { (Neutral } \\
\text { Attitude) }\end{array}$ & $\begin{array}{l}(3 \times 3)+(4 \times 0)+(5 \times 4)): \\
17=2.71(\text { Neutral } \\
\text { Attitude) }\end{array}$ \\
\hline Q15 & $\begin{array}{l}\text { Bahasa Osing adalah bahasa daerah } \\
\text { tersendiri asli Banyuwangi, bukan } \\
\text { bagian dari bahasa Jawa } \\
\text { 'Basa Osing is the independent } \\
\text { language from Banyuwangi, not } \\
\text { part of Javanese' }\end{array}$ & $\begin{array}{l}1(\mathrm{~N}=3) \\
2(\mathrm{~N}=2) \\
3(\mathrm{~N}=15) \\
4(\mathrm{~N}=8) \\
5(\mathrm{~N}=32) \\
\sum=((1 \times 3)+(2 \times 2)+ \\
(3 \times 15)+(4 \times 8)+ \\
(5 \times 32)): 60=\mathbf{4 . 0 7} \\
\text { (Positive Attitude) }\end{array}$ & $\begin{array}{l}1(\mathrm{~N}=2) \\
2(\mathrm{~N}=4) \\
3(\mathrm{~N}=7) \\
4(\mathrm{~N}=3) \\
5(\mathrm{~N}=7) \\
\sum=((1 \times 2)+(2 \times 4)+ \\
(3 \times 7)+(4 \times 3)+(5 \times 7)): \\
23=\mathbf{3 . 3 9} \text { (Positive } \\
\text { Attitude) }\end{array}$ & $\begin{array}{l}1(\mathrm{~N}=0) \\
2(\mathrm{~N}=0) \\
3(\mathrm{~N}=2) \\
4(\mathrm{~N}=3) \\
5(\mathrm{~N}=12) \\
\sum=((1 \times 0)+(2 \times 0)+ \\
(3 \times 2)+(4 \times 3)+(5 \times 12)) \\
17=4.59(\text { Positive } \\
\text { Attitude) }\end{array}$ \\
\hline
\end{tabular}

From the table above, it appears that in the aspect of pride, group I is dominant with a positive attitude. Group I considers Basa Osing to be better (Q7) and its mastery is more important than Javanese (Q1). This group also considers speaking in Basa Osing is not outdated (Q4). This perspective shows that group I, even though they are in the young age, they still have an awareness of the existence of its own local language. However, group I argues that to be part of the Osing tribe does not have to be able to speak Basa Osing. Another thing that was seen from how group I answered the questionnaire was their lack of understanding of the language status of Basa Osing, shown in Q10 and Q15 which had the same core, but they answered with different answers.

From all the questions answered, participants from group II seemed to show a positive attitude more. However, again, they cannot identify their own language status (Q10 and Q15). These two questions are similar in meaning but different in words, but they answered with different answers. It shows that they lack of knowledge about their own language.

Similar to group I and II, group III also has a neutral attitude towards the Q10 statement. This is confusing when the same question in Q15 shows otherwise, even though the two statements together explain and underline that Basa Osing is a language that can independently stand alone. Apparently, participants in group III also experienced similar confusion over the linguistic status of their local languages, as well as group I and group II. But it can be seen from the score of each statement, group III outperforms from all other groups. 


\section{Language Loyalty}

Language loyalty means persistence or obedience to use, and maintain a language. It also includes preventing the entry of other influences into the language. Unlike the language pride aspect, this language loyalty aspect talks more about the "usage", not about the respect only. Different aspects apparently are not as positive as the pride aspect. In group I, language loyalty aspect is dominant with neutral attitude. Regarding willingness to use language, preservation, and loyalty, group II shows an attitude that is not much different from group I, but a little better. Group II shows a positive attitude of 50\% and the remaining $50 \%$ is neutral. Unlike the previous 2 groups, group III is not only outperformed in the pride aspect, but also in the aspects of language loyalty. Group III shows $100 \%$ positive attitude towards statements that contain aspects of loyalty. It can be indicated by the details of the score below.

Table 2. Language Loyalty Score Based on The Age Groups

\begin{tabular}{|c|c|c|c|c|}
\hline & Statements & Group I & Group II & Group III \\
\hline Q2 & $\begin{array}{l}\text { Anak-anak Anda perlu } \\
\text { menguasai bahasa Osing } \\
\text { 'Your children need to master } \\
\text { Basa Osing' }\end{array}$ & $\begin{array}{l}1(\mathrm{~N}=3) \\
2(\mathrm{~N}=6) \\
3(\mathrm{~N}=21) \\
4(\mathrm{~N}=13) \\
5(\mathrm{~N}=10) \\
\sum=((1 \times 3)+(2 \times 6)+ \\
(3 \times 21)+(4 \times 13)+(5 \times 17)): \\
60=\mathbf{3 . 5 8}(\text { Positive } \\
\text { Attitude) }\end{array}$ & $\begin{array}{l}1(\mathrm{~N}=1) \\
2(\mathrm{~N}=1) \\
3(\mathrm{~N}=11) \\
4(\mathrm{~N}=5) \\
5(\mathrm{~N}=5) \\
\sum=((1 \times 1)+(2 \times 1)+ \\
(3 \times 11)+(4 \times 5)+(5 \times 5)): \\
23=\mathbf{3 . 5 2}(\text { Positive } \\
\text { Attitude) }\end{array}$ & $\begin{array}{l}1(\mathrm{~N}=0) \\
2(\mathrm{~N}=0) \\
3(\mathrm{~N}=4) \\
4(\mathrm{~N}=5) \\
5(\mathrm{~N}=8) \\
\sum=((1 \times 0)+(2 \times 0)+ \\
(3 \times 4)+(4 \times 5)+ \\
(5 \times 8)): 17=\mathbf{4 . 2 4} \\
\text { (Positive Attitude) }\end{array}$ \\
\hline Q5 & $\begin{array}{l}\text { Lebih baik berbicara bahasa } \\
\text { Jawa karena lebih banyak } \\
\text { orang yang memahami } \\
\text { daripada bahasa Osing } \\
\text { 'It's better to speak Javanese } \\
\text { because there are more } \\
\text { people understand than Basa } \\
\text { Osing' }\end{array}$ & $\begin{array}{l}1(\mathrm{~N}=6) \\
2(\mathrm{~N}=12) \\
3(\mathrm{~N}=25) \\
4(\mathrm{~N}=12) \\
5(\mathrm{~N}=5) \\
\sum=((1 \times 6)+(2 \times 12)+ \\
(3 \times 25)+(4 \times 12)+(5 \times 5)): \\
60=\mathbf{2 . 9 7}(\text { Neutral } \\
\text { Attitude) }\end{array}$ & $\begin{array}{l}1(\mathrm{~N}=1) \\
2(\mathrm{~N}=5) \\
3(\mathrm{~N}=13) \\
4(\mathrm{~N}=3) \\
5(\mathrm{~N}=1) \\
\sum=((1 \times 1)+(2 \times 5)+ \\
(3 \times 13)+(4 \times 3)+(5 \times 1)): \\
23=\mathbf{2 . 9 1}(\text { Neutral } \\
\text { Attitude) }\end{array}$ & $\begin{array}{l}1(\mathrm{~N}=0) \\
2(\mathrm{~N}=3) \\
3(\mathrm{~N}=6) \\
4(\mathrm{~N}=2) \\
5(\mathrm{~N}=6) \\
\sum=((1 \times 0)+(2 \times 3)+ \\
(3 \times 6)+(4 \times 2)+ \\
(5 \times 6)): 17=\mathbf{3 . 6 5} \\
\text { (Positive Attitude) }\end{array}$ \\
\hline Q8 & $\begin{array}{l}\text { Saya lebih sering } \\
\text { menggunakan bahasa Osing } \\
\text { daripada bahasa Jawa } \\
\text { 'I speak Basa Osing more } \\
\text { often than Javanese' }\end{array}$ & $\begin{array}{l}1(\mathrm{~N}=16) \\
2(\mathrm{~N}=16) \\
3(\mathrm{~N}=19) \\
4(\mathrm{~N}=3) \\
5(\mathrm{~N}=6) \\
\sum=((1 \times 16)+(2 \times 16)+ \\
(3 \times 19)+(4 \times 3)+(5 \times 6)): \\
60=\mathbf{2 . 4 5}(\text { Neutral } \\
\text { Attitude) }\end{array}$ & $\begin{array}{l}1(\mathrm{~N}=2) \\
2(\mathrm{~N}=6) \\
3(\mathrm{~N}=9) \\
4(\mathrm{~N}=4) \\
5(\mathrm{~N}=2) \\
\sum=((1 \times 2)+(2 \times 6)+ \\
(3 \times 9)+(4 \times 4)+(5 \times 2)): \\
23=\mathbf{2 . 9 1}(\text { Neutral } \\
\text { Attitude) }\end{array}$ & $\begin{array}{l}1(\mathrm{~N}=0) \\
2(\mathrm{~N}=0) \\
3(\mathrm{~N}=6) \\
4(\mathrm{~N}=5) \\
5(\mathrm{~N}=6) \\
\sum=((1 \times 0)+(2 \times 0)+ \\
(3 \times 6)+(4 \times 5)+ \\
(5 \times 6)): 17=\mathbf{4 . 0 0} \\
(\text { Positive Attitude })\end{array}$ \\
\hline Q9 & Kalau mau lebih akrab di & $1(\mathrm{~N}=13)$ & $1(\mathrm{~N}=4)$ & $1(\mathrm{~N}=0)$ \\
\hline
\end{tabular}




\begin{tabular}{|c|c|c|c|c|}
\hline & $\begin{array}{l}\text { tempat kerja / sekolah, Anda } \\
\text { perlu menguasai bahasa } \\
\text { Osing } \\
\text { 'If you want to be closer to } \\
\text { people at work / school, you } \\
\text { need to master Basa Osing' }\end{array}$ & $\begin{array}{l}2(\mathrm{~N}=19) \\
3(\mathrm{~N}=20) \\
4(\mathrm{~N}=6) \\
5(\mathrm{~N}=2) \\
\sum=((1 \times 13)+(2 \times 19)+ \\
(3 \times 20)+(4 \times 6)+(5 \times 2)): \\
60=2.42(\text { Neutral } \\
\text { Attitude) }\end{array}$ & $\begin{array}{l}2(\mathrm{~N}=4) \\
3(\mathrm{~N}=8) \\
4(\mathrm{~N}=7) \\
5(\mathrm{~N}=0) \\
\sum=((1 \times 4)+(2 \times 4)+ \\
(3 \times 8)+(4 \times 7)+(5 \times 0)): \\
23=2.78(\text { Neutral } \\
\text { Attitude) }\end{array}$ & $\begin{array}{l}2(\mathrm{~N}=2) \\
3(\mathrm{~N}=6) \\
4(\mathrm{~N}=3) \\
5(\mathrm{~N}=6) \\
\sum=((1 \times 0)+(2 \times 2)+ \\
(3 \times 6)+(4 \times 3)+ \\
(5 \times 6)): 17=3.76 \\
\text { (Positive Attitude) }\end{array}$ \\
\hline Q11 & $\begin{array}{l}\text { Pelestarian bahasa Osing } \\
\text { dimulai dengan seringnya } \\
\text { digunakan } \\
\text { 'Basa Osing preservation } \\
\text { starts with using it frequently' }\end{array}$ & $\begin{array}{l}1(\mathrm{~N}=0) \\
2(\mathrm{~N}=2) \\
3(\mathrm{~N}=6) \\
4(\mathrm{~N}=18) \\
5(\mathrm{~N}=34) \\
\sum=((1 \times 0)+(2 \times 2)+(3 \times 6) \\
+(4 \times 18)+(5 \times 34)): 60= \\
4.40 \text { (Positive Attitude) }\end{array}$ & $\begin{array}{l}1(\mathrm{~N}=2) \\
2(\mathrm{~N}=2) \\
3(\mathrm{~N}=5) \\
4(\mathrm{~N}=3) \\
5(\mathrm{~N}=11) \\
\sum=((1 \times 2)+(2 \times 2)+ \\
(3 \times 5)+(4 \times 3)+(5 \times 11)): \\
23=\mathbf{3 . 8 3}(\text { Positive } \\
\text { Attitude) }\end{array}$ & $\begin{array}{l}1(\mathrm{~N}=0) \\
2(\mathrm{~N}=0) \\
3(\mathrm{~N}=2) \\
4(\mathrm{~N}=1) \\
5(\mathrm{~N}=14) \\
\sum=((1 \times 0)+(2 \times 0)+ \\
(3 \times 2)+(4 \times 1)+ \\
(5 \times 14)): 17=\mathbf{4 . 7 1} \\
\text { (Positive Attitude) }\end{array}$ \\
\hline Q12 & $\begin{array}{l}\text { Bahasa Jawa lebih baik } \\
\text { dipelajari sebagai mulok di } \\
\text { sekolah-sekolah daripada } \\
\text { bahasa Osing } \\
\text { 'Javanese is better taught as } \\
\text { local content in schools than } \\
\text { Basa Osing' }\end{array}$ & $\begin{array}{l}1(\mathrm{~N}=3) \\
2(\mathrm{~N}=6) \\
3(\mathrm{~N}=31) \\
4(\mathrm{~N}=10) \\
5(\mathrm{~N}=10) \\
\sum=((1 \times 3)+(2 \times 6)+ \\
(3 \times 31)+(4 \times 10)+(5 \times 10)): \\
60=\mathbf{3 . 3 0}(\text { Neutral } \\
\text { Attitude) }\end{array}$ & $\begin{array}{l}1(\mathrm{~N}=0) \\
2(\mathrm{~N}=3) \\
3(\mathrm{~N}=12) \\
4(\mathrm{~N}=2) \\
5(\mathrm{~N}=6) \\
\sum=((1 \times 0)+(2 \times 3)+ \\
(3 \times 12)+(4 \times 2)+(5 \times 6)): \\
23=\mathbf{3 . 4 8}(\text { Positive } \\
\text { Attitude) }\end{array}$ & $\begin{array}{l}1(\mathrm{~N}=1) \\
2(\mathrm{~N}=2) \\
3(\mathrm{~N}=3) \\
4(\mathrm{~N}=2) \\
5(\mathrm{~N}=9) \\
\sum=((1 \times 1)+(2 \times 2)+ \\
(3 \times 3)+(4 \times 2)+ \\
(5 \times 9)): 17=\mathbf{3 . 9 4} \\
\text { (Positive Attitude) }\end{array}$ \\
\hline
\end{tabular}

In fact, like what is explained in the table above, participants in group I do not use Basa Osing that often and they use more Javanese in their daily life (Q8), including in their office and school (Q9). This both questions (Q8 and Q9) shows the lowest score with more than half of the participants disagree. It shows that, even they are proud of their local language, it does not mean they want to use it every day. In fact, they realized that the preservation of the Basa Osing began with the frequent use of the language itself (Q11). However, being aware does not change their habits to often use Basa Osing. Researcher found, there is confusion from the participants of group I on deciding which language is better, using Basa Osing or Javanese. In the previous question in the aspect of pride, participants showed a positive attitude to the question 'Mastering Osing is more important than Javanese' (Q1) but when the same question was developed into 'It's better to speak Javanese because there are more people understand than Basa Osing' (Q5 ), participants show a neutral attitude. This is also seen in question number 12, participants also shows a neutral attitude for what language is better used in local content for schools. Participants did not show loyalty to their local 
language, nor agree to use Javanese (neutral). However, as a young generation, participants in group I still want the next generation, their children and grandchildren to master the Osing language (Q2). Actually, it would be difficult if they do not use Basa Osing every day, but want to see the next generation speak Basa Osing.

Whereas, from group II, the scores they obtained in answering questions that contain aspects of loyalty, they show positive attitudes towards the statements that are related to conservation, such as children, local content in schools (Q2, Q11, Q13). However,they are being neutral in statements that are related to real practice and self involvement. They claim that they don't use Basa Osing more often than Javanese (Q8), they also don't use Basa Osing in their work and school to make the situation more intimate (Q9).

After seeing the score obtained by group III participants, it is quite significant when it is compared with the group I and group II scores. It shows that group III participants as Osing speakers often use Basa Osing as a means of communication (Q8), and to create the intimate atmosphere in the office (Q9). Although not many people understand Basa Osing, speakers in group III, do not give up on using Basa Osing (Q5) more often, because participants assume that their own language is better than Javanese. Regarding the preservation of Basa Osing, group III agree to start from small things that can be done by themselves, namely by using it (Q11). Participants also agree that the next generation needs to master Basa Osing (Q2) and obtain knowledge of Basa Osing from the local content in school (Q12).

\section{Awareness of The Norms}

The last aspect is the awareness of language norms. Speakers who have a high awareness of norms, will aware to the use of the language correctly and politely. Therefore, speakers who have a positive attitude are not only proud and loyal to their language, but also must have knowledge about how to use the language. In this context, group I shows a neutral attitude (100\%) to all questions that contain this aspect. Group II shows at least an increase compared to group I which do not show a positive attitude at all. Being compared with group I, group II has a positive attitude of around 33\%, and $67 \%$ is neutral. The best scores in this aspect still goes to group III which has $67 \%$ of positive attitude and the rest $33 \%$ is neutral. The following table is a list of questions that asked to participants and their scores. 
Table 3. Awareness of The Language Norms Score Based on The Age Groups

\begin{tabular}{|c|c|c|c|c|}
\hline & Statements & Group I & Group II & Group III \\
\hline Q3 & $\begin{array}{l}\text { Berbicara dalam bahasa } \\
\text { Osing di depan orang yang } \\
\text { tidak mengerti bahasa } \\
\text { tersebut tidak sopan } \\
\text { 'Speaking in Basa Osing in } \\
\text { front of people who do not } \\
\text { understand the language is } \\
\text { impolite' }\end{array}$ & $\begin{array}{l}1(\mathrm{~N}=8) \\
2(\mathrm{~N}=6) \\
3(\mathrm{~N}=21) \\
4(\mathrm{~N}=15) \\
5(\mathrm{~N}=10) \\
\sum=((1 \times 8)+(2 \times 6)+ \\
(3 \times 21)+(4 \times 15)+ \\
(5 \times 10)): 60=\mathbf{3 . 2 2} \\
(\text { Neutral Attitude })\end{array}$ & $\begin{array}{l}1(\mathrm{~N}=1) \\
2(\mathrm{~N}=2) \\
3(\mathrm{~N}=11) \\
4(\mathrm{~N}=4) \\
5(\mathrm{~N}=5) \\
\sum=((1 \times 1)+(2 \times 2)+ \\
(3 \times 11)+(4 \times 4)+ \\
(5 \times 5)): 23=\mathbf{3 . 4 3} \\
(\text { Positive Attitude })\end{array}$ & $\begin{array}{l}1(\mathrm{~N}=6) \\
2(\mathrm{~N}=2) \\
3(\mathrm{~N}=2) \\
4(\mathrm{~N}=5) \\
5(\mathrm{~N}=2) \\
\sum=((1 \times 6)+(2 \times 2)+ \\
(3 \times 2)+(4 \times 5)+ \\
(5 \times 2)): 17=\mathbf{2 . 7 1} \\
\text { (Neutral Attitude) }\end{array}$ \\
\hline Q13 & $\begin{array}{l}\text { Bahasa Jawa lebih mudah } \\
\text { digunakan daripada bahasa } \\
\text { Osing } \\
\text { 'Javanese is easier to use } \\
\text { than Basa Osing' }\end{array}$ & $\begin{array}{l}1(\mathrm{~N}=11) \\
2(\mathrm{~N}=18) \\
3(\mathrm{~N}=20) \\
4(\mathrm{~N}=8) \\
5(\mathrm{~N}=3) \\
\sum=((1 \times 11)+(2 \times 18)+ \\
(3 \times 20)+(4 \times 8)+(5 \times 3)): \\
60=\mathbf{2 . 5 7}(\text { Neutral } \\
\text { Attitude) }\end{array}$ & $\begin{array}{l}1(\mathrm{~N}=4) \\
2(\mathrm{~N}=7) \\
3(\mathrm{~N}=5) \\
4(\mathrm{~N}=4) \\
5(\mathrm{~N}=3) \\
\sum=((1 \times 4)+(2 \times 7)+ \\
(3 \times 5)+(4 \times 4)+(5 \times 3)): \\
23=\mathbf{2 . 7 8}(\text { Neutral } \\
\text { Attitude) }\end{array}$ & $\begin{array}{l}1(\mathrm{~N}=1) \\
2(\mathrm{~N}=1) \\
3(\mathrm{~N}=5) \\
4(\mathrm{~N}=3) \\
5(\mathrm{~N}=7) \\
\sum=((1 \times 1)+(2 \times 1)+ \\
(3 \times 5)+(4 \times 3)+ \\
(5 \times 7)): 17=\mathbf{3 . 8 2} \\
\text { (Positive Attitude) }\end{array}$ \\
\hline Q14 & $\begin{array}{l}\text { Bahasa Osing lebih kasar } \\
\text { digunakan untuk berbicara } \\
\text { dengan orang yang lebih tua } \\
\text { dibandingkan dengan bahasa } \\
\text { Jawa } \\
\text { 'Talking to older people is } \\
\text { better to use Javanese, } \\
\text { because Basa Osing is more } \\
\text { rude than Javanese' }\end{array}$ & $\begin{array}{l}1(\mathrm{~N}=18) \\
2(\mathrm{~N}=13) \\
3(\mathrm{~N}=17) \\
4(\mathrm{~N}=9) \\
5(\mathrm{~N}=3) \\
\sum=((1 \times 18)+(2 \times 13)+ \\
(3 \times 17)+(4 \times 9)+(5 \times 3)): \\
60=2.43(\text { Neutral } \\
\text { Attitude) }\end{array}$ & $\begin{array}{l}1(\mathrm{~N}=4) \\
2(\mathrm{~N}=5) \\
3(\mathrm{~N}=10) \\
4(\mathrm{~N}=3) \\
5(\mathrm{~N}=1) \\
\sum=((1 \times 4)+(2 \times 5)+ \\
(3 \times 10)+(4 \times 3)+ \\
(5 \times 1)): 23=\mathbf{2 . 6 5} \\
\text { (Neutral Attitude) }\end{array}$ & $\begin{array}{l}1(\mathrm{~N}=1) \\
2(\mathrm{~N}=3) \\
3(\mathrm{~N}=6) \\
4(\mathrm{~N}=1) \\
5(\mathrm{~N}=6) \\
\sum=((1 \times 1)+(2 \times 3)+ \\
(3 \times 6)+(4 \times 1)+ \\
(5 \times 6)): 17=\mathbf{3 . 4 7} \\
\text { (Positive Attitude) }\end{array}$ \\
\hline
\end{tabular}

From the table above, it can be seen that group I does not show a positive attitude towards awareness of the norms in Basa Osing. Basa Osing does not have strata or politeness levels, for the same age, older, or younger. This is different with Javanese which has politeness levels, such as ngoko, krama, and krama inggil. Basa Osing can be used for all groups at any age, therefore its usage cannot be said as rude (Q14). Apparently, participants in group I might not really understand this rule, so they chose to be neutral about the statement. Similar to Q13, participants show a neutral attitude. With the fact that Basa Osing has no politeness levels, Basa Osing should be easier for the speakers than Javanese. The participants in group I also expressed neutrality in the statement that speaking in Basa Osing in front of people who did not understand the language is impolite (Q3). As a speaker of a particular language, speaking in a language that is not understood by the person around or the other 
person can be considered impolite and can give the impression of not respecting the other person's existence.

Similar to the previous group, group II also does not seem to have the knowledge that Basa Osing does not have the level of politeness like Javanese. Because it was influenced by the Javanese, the use of Basa Osing seemed to be ruder. However, this group has realized that speaking Basa Osing in front of people who do not understand the language is not polite, this can be seen from their score that shows a positive attitude.

Participants in group III has an awareness that Basa Osing do not have a level of politeness, therefore the use of Basa Osing is not considered as rude (Q3) when it is used to talk to older people. Participants also agree with the statement that Basa Osing is easier to use than Javanese (Q13). However, neutrality is also shown in group III because participants consider speaking Basa Osing in front of people who do not understand the language is considered as polite $(\mathrm{Q} 3)$.

Based on the explanation of each group, it can be concluded that each age group has a different perspective towards Basa Osing, including language pride, language loyalty, and awareness of language norms. When it is seen from the score, the group whose participants were the oldest (group III) had the highest positivity. As can be seen in the chart below, the younger the participants, the more indicated results are more neutral, not positive.

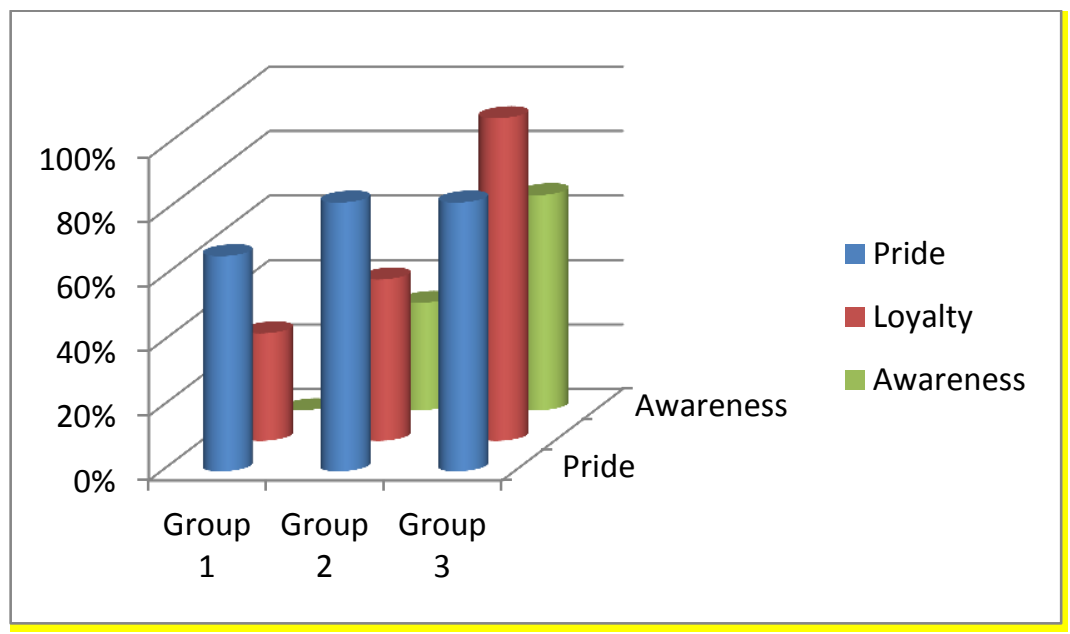

Figure 1. Language Attitude of Basa Osing Speakers 
Thus, Basa Osing is very possible to experience language shifts in the future if the perspective of the society gets worse. Moreover, the young generation in Banyuwangi is not provided with the knowledge of Basa Osing itself at school. It can influence their sense of pride, sense of belonging towards their own local language. It is not impossible that in the future, Banyuwangi sub-district people will use Javanese only because basically Basa Osing has many similarities with Javanese. This is important to be highlighted because of the lower use of Basa Osing among young people.

According to Budiono (2015), Banyuwangi sub-district is one of the districts dominated by Basa Osing users. However, when compared with the results obtained from the attitude of the Banyuwangi sub-district people this year (2019), it is very possible that Banyuwangi sub-district will be dominated by other language users. Banyuwangi sub-district people actually still has a sense of pride towards their own local language, this is indicated by the number of language pride score that tends to be higher than other aspects. However, to practice and use Basa Osing continuously in daily life, group dominated by participants with young age has smaller score. Briefly, language attitude of Basa Osing speakers has worsened.

\section{Conclusion}

This research shows that Basa Osing speakers in old generation show a more positive attitude than young speakers. Group III or the oldest group shows a positive attitude towards Basa Osing as much as $70 \%$ of the total participants, whereas only $40 \%$ of group II participants, and $30 \%$ of group I participants who show a positive perspective. Basa Osing is very possible to experience language shifts in the future if the perspective of the society gets worse. Moreover, the young generation in Banyuwangi is not provided with the knowledge of Basa Osing itself at school. It can influence their sense of pride, sense of belonging towards their own local language. It is not impossible that in the future, Banyuwangi sub-district people will use Javanese only because basically Basa Osing has many similarities with Javanese. This is important to be highlighted because of the lower use of Basa Osing among young people.

\section{References}

Arps, Bernard. 2010. Geliat Bahasa Selaras Zaman Perubahan Bahasa-bahasa di Indonesia Pasca-Order Baru. Research Institute for Languages and Cultures of Asia and Africa (ILCAA): Tokyo University of Foreign Studies. 
Badan Pusat Statistik. 2012. Kewarganegaraan Suku Bangsa Agama dan Bahasa Sehari-hari Penduduk Indonesia. Jakarta: Badan Pusat Statistik.

Budiono, Satwiko. 2015. Variasi Bahasa di Kabupaten Banyuwangi: Penelitian Dialektologi. Depok: Undergraduate Thesis, Universitas Indonesia. Unpublished.

Cohn et al. 2013. Kuesioner Penggunaan Bahasa Sehari-hari. Jakarta: Pusat Kajian Bahasa dan Budaya (PKBB) Unika Atma Jaya.

Garvin, P.L. \& Mathiot, M. 1968. The Urbanization of the Guarani Language: A Problem in Language and Culture. In Readings in the Sociology of Language (Ed. by Fishman, Joshua A.), pp. 365-374.

Herusantosa, Suparman. 1987. Bahasa Using di Kabupaten Banyuwangi. Dissertation. Jakarta: Universitas Indonesia. Unpublished.

Jendra, Made Iwan Indrawan. 2010. Sociolinguistics: The Study of Societies' Languages. Yogyakarta: Graha Ilmu.

Legene, et. al. 2015. Sites, Bodies, and Stories: Imagining Indonesian History. Singapore: National University of Singapore Press.

Maulidya, Nurul. 2015. Lexical Differences in Osing Variety Spoken by People in Banyuwangi Regency. Surabaya: Undergraduate Thesis, Universitas Airlangga. Unpublished.

Pemerintah Provinsi Jawa Timur. 2014. Peraturan Gubernur Jawa Timur Nomor 19 Tahun 2014 Tentang Mata Pelajaran Bahasa Daerah Sebagai Muatan Lokal Wajib di Sekolah/Madrasah. Surabaya: Pemprov Jatim.

Putra, A.N. \& Welly, J. 2015. Analyzing Engagement Of Outsource Employee Study Case. Journal Of Business And Management, Vol. 4, No.8, 901-912.

Surani, S., Suparmin, Sudjarwi, I.C., \& Hadiri. 1987. Fonologi Bahasa Jawa Dialect Banyuwangi. Jawa Timur: Proyek Penelitian Bahasa Indonesia dan Daerah, Departemen Pendidikan dan Kebudayaan Propinsi Jawa Timur. 